\title{
PETROGRAPHIC CHARACTERISTICS OF HOST AND ASSOCIATED ROCKS IN THE Pb- Zn DEPOSIT OF RAMPURA-AGUCHA AREA, BHILWARA BELT (RAJASTHAN) INDIA
}

\author{
Rajiullah Khan ${ }^{1}$, Mohd Shaif ${ }^{2}$, F.N. Siddiquie ${ }^{3}$ and Masood Ahmed ${ }^{4}$ \\ ${ }^{1}$ Research Scholar, ${ }^{2}$ Assistant Professor, ${ }^{3}$ Professor, ${ }^{4}$ Independent Scholar \\ Department of Geology, Aligarh Muslim University, Aligarh (UP), India \\ Email: rajiullahkhan17@gmail.com, msaif125@gmail.com, fnaseem2000@yahoo.com
}

\begin{abstract}
The present study is to confine the Rampura-Agucha area, Bhilwara district, Rajasthan, which occurs in Bhilwara Super group at the contact with Banded Gneissic Complex. The Bhilwara belt is a thick pile of metasedimentary rocks in the eastern part of Aravalli-Delhi belt that consists dominant litho-units viz: graphite-sillimanite-garnet schist, garnet-biotite-sillimanite gneisses with garnet-bearing leucosomes as well as amphibolites, pegmatites and some scattered calc-silicates while the Pb-Zn ore deposit mainly occurs within graphite-biotite-sillimanite schist. The mineralogical assemblages of host rocks explain that they are formed under the high grade of metamorphism, primarily upper amphibolite to granulite facies condition. These Pb-Zn bearing ore are intimately associated with schist. The inclusions of quartz are common in garnets, while ore minerals also contain the inclusion of quartz and feldspar. The highly fractured grains of garnet, hornblende and pyroxene due to deformation, and pressure are observed in these host rocks while the contact between the quartz grains is of suture type in the calc-silicate rock.
\end{abstract}

Key words: $\mathrm{Pb}-\mathrm{Zn}$, Bhilwara Super group, Petrography, Rocks and Minerals

\section{Introduction}

The $\mathrm{Pb}-\mathrm{Zn}$ deposits of the Rampura-Agucha area occur within Mesoproterozoic metasedimentary rocks belonging to the Bhilwara supracrustal belt of Aravalli-Delhi orogen in the Bhilwara district of Rajasthan state (Deb \& Sarkar, 1990), which is located about $220 \mathrm{~km}$ to the $\mathrm{SW}$ of the state capital, Jaipur. The area is very much renowned due to its largest $\mathrm{Pb}-\mathrm{Zn}$ deposits, where the ore body is extending over a strike length of about $1.55 \mathrm{~km}$ with on average width of $60 \mathrm{~m}$ while at places the maximum width goes up to $100 \mathrm{~m}$. The rough estimation of $\mathrm{Pb}-\mathrm{Zn}$ ore reserve is around 63.65 million tonnes with an average content of 13.38 percent $\mathrm{Zn}$, 1.9 percent $\mathrm{Pb}$ and 9.58 percent $\mathrm{Fe}$ (Gandhi et al., 1984). The $\mathrm{Pb}-\mathrm{Zn}$ bearing rocks encountered in the present study area are metamorphosed to mainly upper amphibolite to granulite facies, estimated by Ranawat et al. (1988), Deb \& Sarkar (1990). Several pioneer workers Gandhi et al. (1984), Ranawat et al. (1988), Ranawat \& Sharma (1990) and Sharma \& Singh (1990) are continuously involved in the study of these ores and its associated rocks. Recently, Chattopadhyay (2017), mentioned that a large scale of remobilization of ore during metamorphism is evidenced mainly in the cleavage and fracture of the associated silicates. Finally, the present authors did the petrographic studies of the rocks to understand the petromineralogical associations in the study area. However, such type of study always provides relevant information over mineralogy, textural properties, P-T conditions and paragenetic history of rocks, which formed the base for depth studies of the area.

\section{Geology of the Study Area}

The regional geology of south-eastern Rajasthan is shown by the Banded Gneissic Complex (BGC), Aravalli Supergroup and Delhi Super group (Heron, 1953). The pre-Aravalli group was renamed as Bhilwara Super group, representing the Bhilwara geological cycle of Archean age, however, there is a controversy regarding the separate status of Bhilwara Super group. According to Raja Rao (1976), Bhilwara Super group is older than the Aravalli but Roy et al. (1981), Naha \& Halyburton (1974 \& 1977) and Naha \& Roy (1983), stress that there is a striking similarity in the structures of the Bhilwara Super group and the Aravalli rocks. The Pb$\mathrm{Zn}$ deposits of Rampura-Agucha area are located close to the Delwara lineament (Gupta et al., 1980) between the Mangalwar complex and the Sandmata complex that form a part of Bhilwara Super group/Banded Gneissic Complex. Geologically, the study area comprises an 
assemblage of pelitic rocks that constitutes the graphite-biotite-sillimanite schist and garnetbiotite-sillimanite gneiss. These pelitic rocks constitute the most dominant lithologic unit exposed in the study area along with garnet-bearing leucosomes, calc-silicate gneisses, amphibolites and pegmatites (Gandhi et al., 1984; Mishra \& Bernhardt, 2009). The host rocks in the study area show NE-SW strike with a steep dip in hanging wall side (750-800SE) and moderate dip in the footwall side (600-650SE). The general strike of the ore zone is parallel to the enclosing rocks (NE-SW) while the dip of the ore zone is varying along the strike. The rocks of the Rampura-Agucha area are metamorphosed sedimentary enclaves with an unknown stratigraphic contact with the Archean basement (Sinha-Roy, 1989). According to Deb and Sehgal (1997), the sequence of litho-units is seen from eastern hanging wall to western footwall of Rampura-Agucha $\mathrm{Pb}-\mathrm{Zn}$ ore deposits are as follows:

- Garnet-biotite-sillimanite gneiss (GBSG) with intermittent bands of amphibolites and calc-silicate rocks, intruded by aplite and pegmatite;

- Graphite-mica-sillimanite schist (ore body);

- GBSG with lenses of amphibolites, quartzo-feldspathic bands and calc-silicate rocks intruded by pegmatite/aplites veins;

- Granite-gneiss;

- Severely mylonitized GBSG;

- Banded and augen gneiss.

The rocks in the area have been subjected to polyphase deformation and metamorphosed up to high grade with zones of mylonite (HZL, 1992). According to Ray (1982), the area around the Rampura-Agucha ore deposits has suffered three-phase of deformation namely-

i. An initial isoclinal folding with a variable plunge and axial plane that produced WNWESE trending folds;

ii. Subsequent isoclinal folding which folded the S1 axial plane about a NE-SW axis;

iii. A weak, local phase of upright, steeply plunging fold.

\section{Figure 01: Simplified geological map of Rampura-Agucha Ore body and Surrounding} Rocks (Simplified after Holler \& Gandhi, 1995)

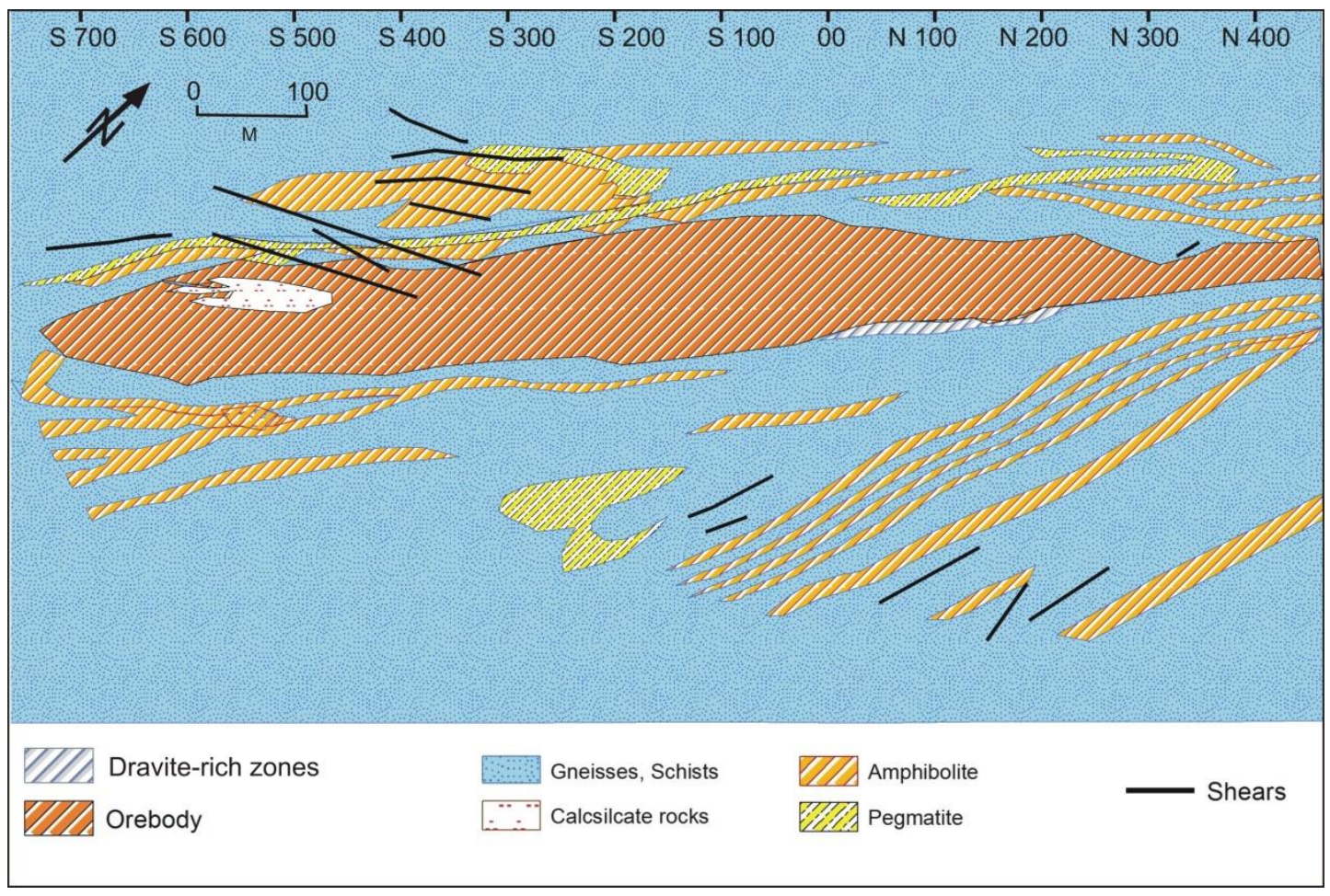

\section{Sampling and Analytical Methods}

The author visited the Rampura-Agucha mines and its surrounding area, Bhilwara District, Rajasthan. Due to the scanty and non- availability of rock exposures in the study area, samples of different rocks types were collected from the Rampura-Agucha mine, small stone queries and available rock exposures along the Mansi River. About 40 samples of all rock types were collected from a different location, from each collected samples, few thin sections were prepared by following Grundmann \& Scholz (2015). Thin sections studied in transmitted light 
under the petrological microscope and powdered the five selected samples to 200 mesh size in grinding mill (for XRD analysis) was carried out in the Department of Geology, AMU., Aligarh. The powdered rock samples were analyzed in the Department of Mechanical Engineering, AMU, Aligarh. The XRD pattern was recorded from 50 to 900 with a step size of 0.050 /sec, using nickel filtered $\mathrm{Cu} \mathrm{Ka}$ radiations. The data was interpreted and plotted by X'pert High Score Plus and Origin Pro 8.5, respectively.

\section{PETROGRAPHY}

\section{Graphite-biotite-sillimanite Schist}

It is the main rock type that hosts the mineralization of the ore. In the field, it shows a very sharp contact with other surrounding rocks and within these rock units, there are few bands of calc-silicates which are barren of ore mineralization except for sporadic specks of pyrite (Gandhi et al., 1984). Megascopically, it is coarse-grained and shows well-developed schistosity and also contains pink color garnet porphyroblasts. The lead and zinc ore are associated with graphite-biotite-sillimanite schist mostly in laminated form. Under the microscope, it chiefly consists of quartz, biotite and sillimanite with a considerable amount of graphite as well as potash feldspar, garnet and opaque minerals. The accessory minerals are apatite and tourmaline. The graphite mineral occurs as a subhedral fragments along with feldspar, biotite, and quartz (Fig.3.e). On the other hand, sillimanite is associated with biotite and garnet along well developed foliation. Deformation in the twin planes of plagioclase commonly observed in the thin section (Fig.3.f). Quartz and biotite are common inclusion in the garnet formed the poikiloblastic texture. Quartz grains are xenoblastic and show undulose extinction. Biotite flakes uniformly cleaved with preferred orientation results in the formation of the schistosity. Generally, garnet grains are fractured and occur same time with biotite and sillimanite. The $2 \theta$ position of different minerals in the graphite-biotite-sillimanite schist of the study area has given in figure 2 .A.

\section{Garnet-biotite-sillimanite Gneiss}

It is the prevailing lithology within and around the mine. It represents a metasedimentary sequence of shale and slate. Megascopically, these rocks are medium to coarse grained, showing gneissose structure. They are foliated and contain the leucocratic bands of quartz and feldspar with insignificant amount of tourmaline alternating with melanocratic layers rich in biotite and garnet. It is very heterogeneous and shows a well-developed augen structure in which fine grained minerals wrapped around the garnet porphyroblasts. Garnet and feldspar porphyroblasts are ranged from few $\mathrm{mm}$ to $100 \mathrm{~mm}$ in size and set in a gneissic to schistose groundmass (Gandhi et al., 1984; Ranawat \& Sharma, 1990; Sharma \& Singh, 1990). Under the thin section studies, gneiss samples are medium to coarse grained and consist of quartz, microcline, plagioclase, sillimanite, garnet, and accessory minerals, including zircon, apatite, tourmaline and magnetite. Garnet grains are highly shattered and show the inclusions of quartz (Fig.3.h). These inclusions are limited to the central part of the garnet porphyroblasts while the outer side is generally lacking any such inclusions. The dominant garnet composition is almandine (Holler, Touret, \& Stumpfl, 1996). Garnet and feldspar occur as a porphyroblast while sillimanite grains occur as needles and form clusters. Biotite occurs as a tabular aggregate with traces of sericite. The $2 \theta$ position of biotite, graphite, quartz and sillimanite in the garnet-biotite-sillimanite gneiss has given in figure 2.B.

\section{Calc-silicate Rock}

The samples of calc-silicate rocks are collected from the Rampura-Agucha open cast mine and Mansi River. It is the minor component of the lithological assemblages and occurs as irregular bands within the gneiss. It is hard and compact, consequently resistant to weathering, forming prominent boulder outcrops. In hand specimens, these rocks are fine to medium grained types with frequent garnet porphyroblasts of various sizes. 
Figure 02. (A) $2 \theta$ Position of biotite, galena, microcline, quartz and sphalerite in Schist; (B) $2 \theta$ Position of biotite, graphite, quartz and sillimanite in Gneiss; (C) $2 \theta$ Position of anorthite, enstatite, labradorite and quartz in Calc- silicate; (D) $2 \theta$ Position of actinolite, andesine, hornblende, labradorite and quartz in Amphibolite; (E) $2 \theta$ Position of biotite, plagioclase and quartz in pegmatite, Bhilwara belt, Rajasthan.
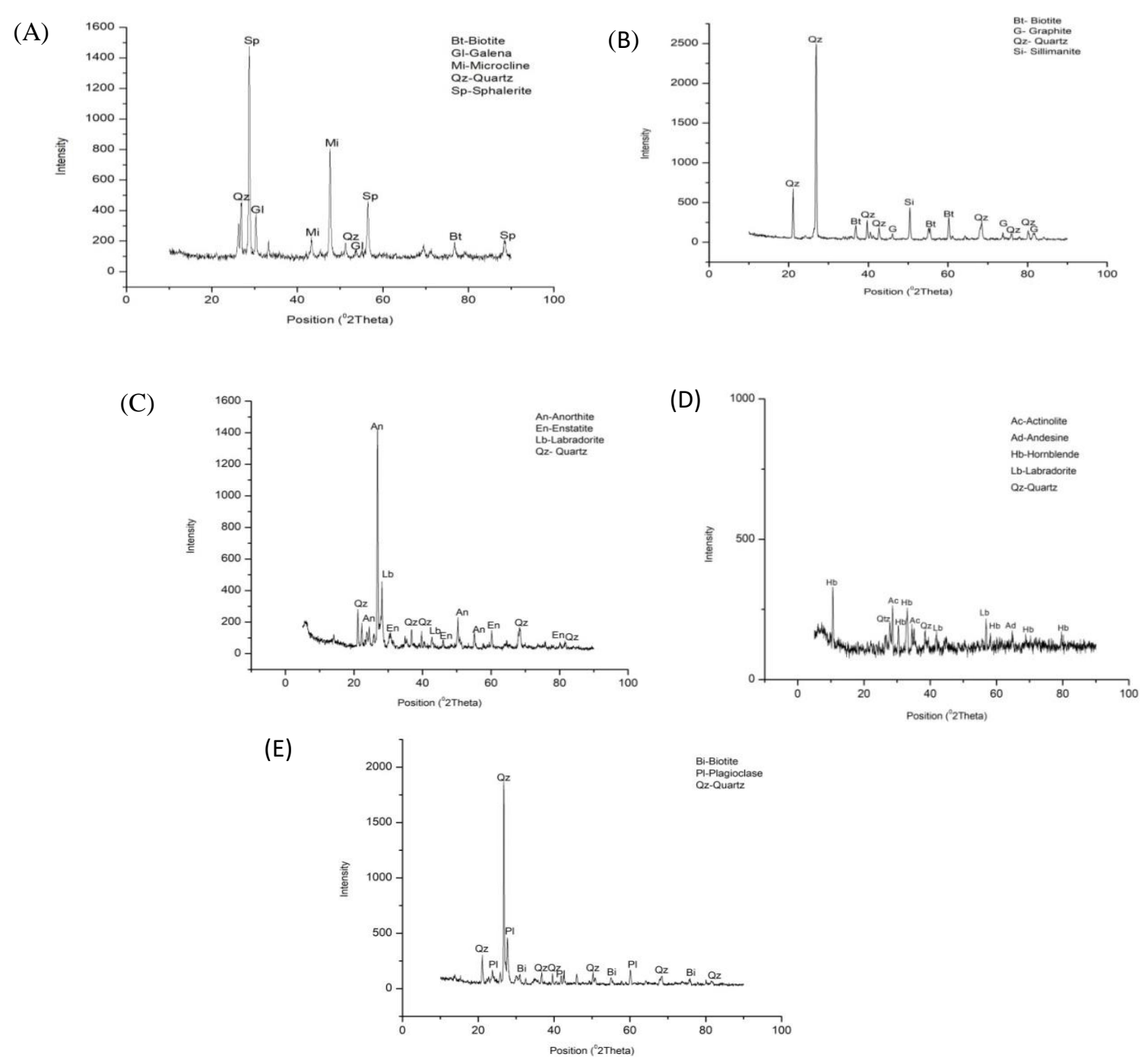

Figure 03: Representative Transmitted Light Microphotograph of Different Rock Units
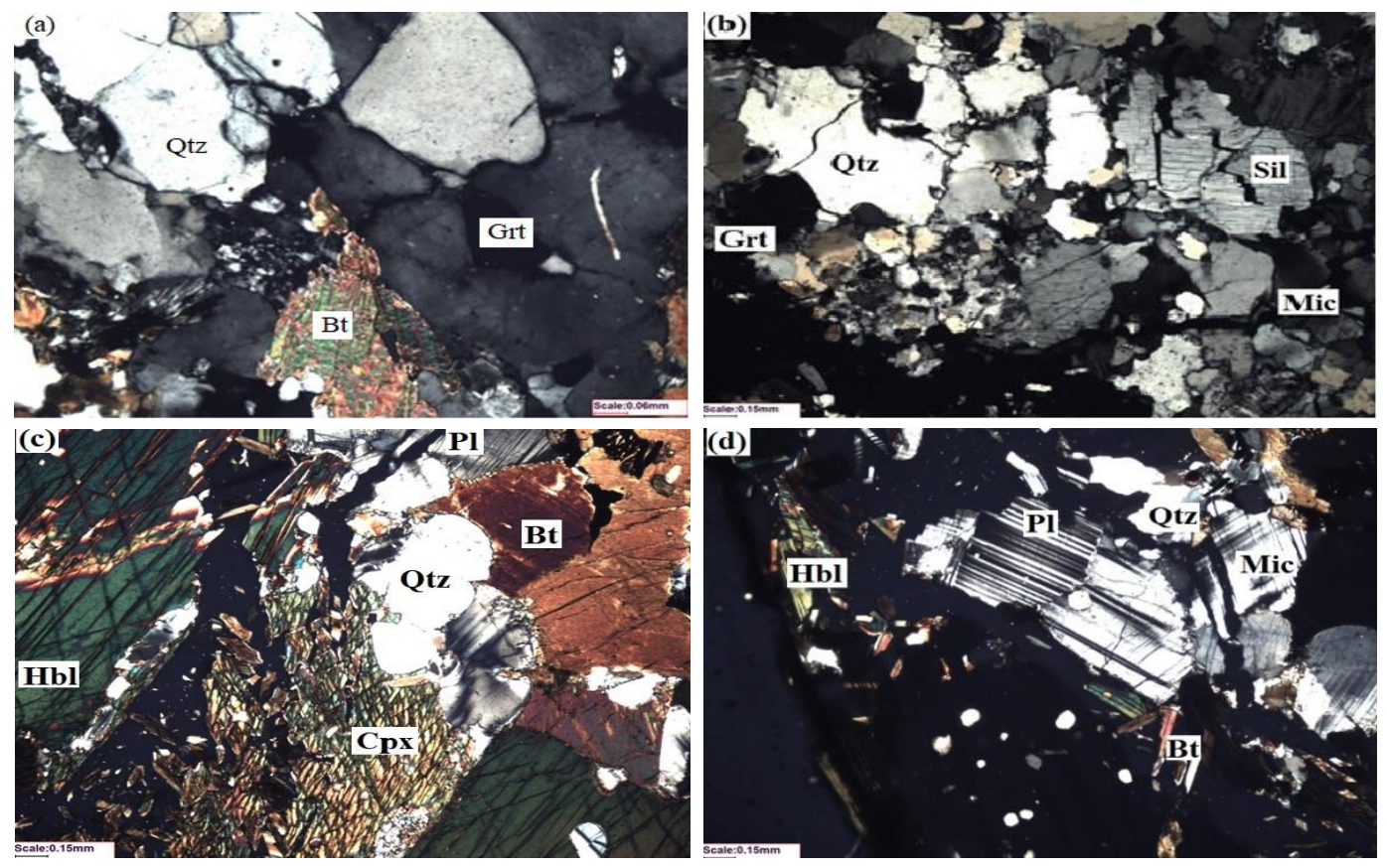
(a) Showing coarse grained quartz (Qtz), biotite (Bt) and garnet (Grt) in Pegmatite, near Bhopalpura village, (b) Showing highly recrystallized quartz grains (suture contact) in calc-silicate at Rampura-Agucha open cast mines, Bhilwara belt, (c) Showing the large hornblende $(\mathrm{Hbl})$ and clinopyroxene (Cpx) crystal breaking down to an aggregate of small crystals (mortar texture) in amphibolite at stone quarry near Amartiya road, (d) Amphibolite, showing hornblende with plagioclase (lamellar twinning), microcline (Mic), quartz and biotite, stone quarry near Amartiya road, Bhilwara belt, Rajathan.

Fine laminations of a millimeter-scale and compositional variations are also seen in this rock. Microscopically, various samples of calc-silicate rock have been taken for petrographic studies which show the presence of diopside, plagioclase and garnet with minor quartz, kfeldspar and rare hornblende as principal constituents, and scapolite, zoisite, titanite and sphene occur as accessory minerals. Plagioclase occurs as tabular and sub-idioblastic grains while microcline grains are xenoblastic to sub-idioblastic grains. Quartz grains are highly crystallized, showing the suture contact (Fig.3.b). The $2 \theta$ positions of different minerals in calcsilicate rock shown in figure 2.C.

\section{Amphibolite}

Amphibolite samples are collected from stone quarry near Amartiya road and Rampura-Agucha mines. Amphibolites in the study area show an inter-fingering relationship with the calc-silicate rocks and occur as bands of different width in the garnet-biotite-sillimanite gneiss. Two types of amphibolite have seen in the study area (i) schistose amphibolite and (ii) granoblastic amphibolite. They are generally medium to coarse grained in nature. Out of both varieties, schistose amphibolites occur as enclaves, while granoblastic amphibolites show intrusive nature with country rocks. Megascopically, it appears dark green to black color, and are generally medium to coarse grained rocks.

Figure 3. (e) Fine grained garnet-biotite-sillimanite schist showing orientation of quartz and micaceous minerals, Rampura-Agucha open cast mines, (f) Garnet-biotite-sillimanite schist, showing the plagioclase with deformation twins, Rampura-Agucha open cast mines, (g) GBSG, showing garnet, microcline (cross hatched twinning) and angular shaped quartz at Mansi river, (h) GBSG, showing inclusions of quartz and biotite in garnet, Mansi river, Bhilwara belt, Rajasthan.
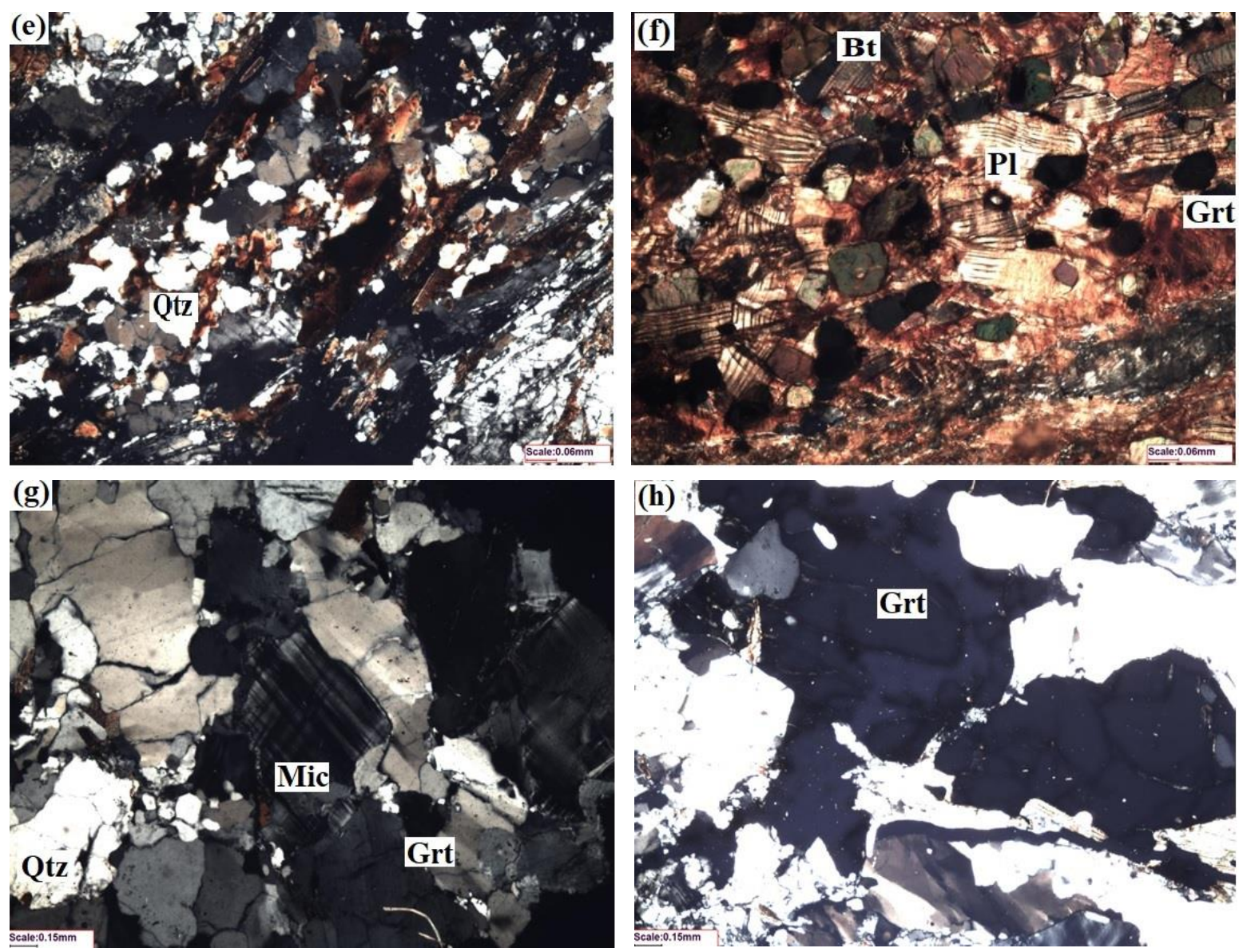
It shows a granoblastic to loosely foliated texture. Garnet grains in the amphibolite of the study area occur as a porphyroblast. Microscopically, it is composed of essentially hornblende, plagioclase and garnet along with diopside, biotite and quartz. Pyroxene and hornblende crystals are breaking down to an aggregate of small crystals forming the mortar texture (3.c). Pyroxene grains are riddled with inclusions of quartz and hornblende, while the hornblende grains are relatively free from the inclusions. Hornblende is showing perfect two set cleavages while both plagioclase and microcline are showing their characteristic properties i.e., lamellar and cross-hatched twinning respectively (Fig.3.d). Triple junctions are clearly seen in the hornblende grain (Fig.3.c), indicating the dynamic recrystallization. According to Roy (2000), amphibolite of the study area to be para-amphibolite formed by high-grade metamorphic facies of impure dolomitic limestone. X-ray diffraction pattern of different minerals in amphibolite has given in fig.2.D.

\section{Pegmatite}

In the study area, the pegmatite samples are collected from Rampura-Agucha mines. Pegmatites are common in the study area with individual pegmatite components may be up to 40 meters in thickness locally (Gandhi et al., 1984). Thin veins of pegmatite are seen as intrusive in the garnet-biotite-sillimanite gneiss, amphibolites and calc-silicate rocks. In hand specimens study, It is coarse grained rocks. Garnet grains of different sizes are also present in the pegmatite. Microscopically, pegmatites consist of mainly coarse grained quartz, plagioclase and biotite with a minor percentage of garnet (Fig. 3.a). Quartz occurs as a xenoblastic grain, while biotite found as elongated grains. Quartz and feldspar form a graphic intergrowth texture. The $2 \theta$ position of biotite, plagioclase and quartz in pegmatite is shown in figure 2.E.

\section{Mineral Assemblages}

Based on petrographic and X-ray diffraction studies of various rock types in the study area, the followings mineralogical assemblages are identified and listed in table1.

Table 01: Mineral Assemblage in the Host and Associated Rocks of the Study Area

\begin{tabular}{|c|l|l|}
\hline$\#$ & \multicolumn{1}{|c|}{ Rock types } & \multicolumn{1}{|c|}{ Mineral assemblages } \\
\hline 1 & Graphite-biotite-sillimanite-schist & $\begin{array}{l}\text { Quartz, biotite, sillimanite, graphite, microcline, garnet, } \\
\text { apatite, tourmaline and opaque minerals }\end{array}$ \\
\hline 2 & Garnet-biotite-sillimanite gneiss & $\begin{array}{l}\text { Quartz, microcline, plagioclase, sillimanite, garnet, zircon, } \\
\text { apatite, tourmaline and magnetite }\end{array}$ \\
\hline 3 & Calc-silicate rock & $\begin{array}{l}\text { Diopside, microcline, anorthite, labradorite, quartz, } \\
\text { enstatite, sillimanite, garnet, scapolite, zoisite, titanite and } \\
\text { sphene }\end{array}$ \\
\hline 4 & Amphibolite & $\begin{array}{l}\text { Hornblende, actinolite, plagioclase (andesine, labradorite), } \\
\text { garnet, diopside, biotite and quartz }\end{array}$ \\
\hline 5 & Pegmatite & Quartz, plagioclase, biotite, tourmaline and garnet \\
\hline
\end{tabular}

\section{Conclusion}

The $\mathrm{Pb}-\mathrm{Zn}$ deposits of the Rampura-Agucha area occur within meso-proterozoic metasedimentary rocks belonging to the Bhilwara supracrustal belt and consist of pelitic rocks that constitute the graphite-biotite-sillimanite schist, garnet-biotite-sillimanite gneisses along with calc-silicate, amphibolite and pegmatite. On the basis of petrographical investigations, it appears that regional metamorphism has played an important role in metamorphism of pelitic rocks up to upper amphibolite to granulite facies, which are the prominent host rocks of Rampura-Agucha $\mathrm{Pb}-\mathrm{Zn}$ deposit. The textures observed in the rocks under investigation reveal the pre-tectonic crystallization of mineral grains as well as the multiphase of deformation. Thin section studies and X-ray diffraction patterns of different rock types in the area suggest the $\mathrm{Pb}$ $\mathrm{Zn}$ ores are found in schist and deposited along the mineral grain boundaries and generally, found as dark color patches in thin sections.

\section{Acknowledgments}

The author is grateful to Prof. Syed Ahmed Ali, Chairman, Department of Geology, AMU, Aligarh, and Dr. S. A. Rashid, Associate Professor, Department of Geology, AMU, for the laboratory work. Mr. Bingi Murli, AGM, Rampura-Agucha mine, his cooperation in field assistance is appreciated. The author is grateful to CSIR-JRF for financial support. 


\section{References}

1. Chattopadhyay, P.K. (2017) The Metamorphic Evolution of the Base Metal Sulphide Deposit of Rampura-Agucha, Raj. Petrographical Evidences. Asian Resonance, 6(4).

2. Deb, M., \& Sarkar, S. C. (1990) Proterozoic tectonic evolution and metallogenesis in the Aravalli-Delhi orogenic complex, northwestern India. Precambrian Research, 46(1-2), 115.

3. Deb, M., \& Sehgal, U. (1997) Petrology, geothermobarometry and COHS fluid compositions in the environs of Rampura-Agucha $\mathrm{Zn}-(\mathrm{Pb})$ ore deposit, Bhilwara District, Rajasthan. Proceedings of the Indian Academy of Sciences-Earth and Planetary Sciences, 106(4), 343-356.

4. Gandhi, S.M., Paliwal, H.V. and Bhatnagar, S.N. (1984) Geology and ore reserve estimates of Rampura-Agucha Zinc-Lead Deposit, Bhilwara District, Rajasthan. J. Geol. Soc. India, 25, 689-705.

5. Gupta, S.N., Arora, Y.K., Mathur, R.K., Iqballuddin, Prasad, B., Sahai. T.N. and Sharma, S.B. (1980) Litho-stratigraphic map of the Aravalli region, Scale 1:100000. Geological Survey of India, Calcutta.

6. Grundmann, G. and Scholz, H. (2015) Preparation methods in Mineralogy \& Geology: The Preparation of thin sections, polished sections, acetate foil prints, preparation for elutriation analysis, and staining tests for the optical and electron microscopy.

7. Heron, A. M. (1953) The geology of central Rajputana. Mem. Geol. Soc. Ind., 79.

8. Holler, W., \& Gandhi, S. M. (1995) Ag-minerals from the metamorphosed RampuraAgucha Pb-Zn deposit, Rajasthan. Econ. Geol, 85, 1236-1251.

9. Höller, W., \& Gandhi, S. M. (1997) Origin of tourmaline and oxide minerals from the metamorphosed Rampura Agucha $\mathrm{Zn}-\mathrm{Pb}-(\mathrm{Ag})$ deposit, Rajasthan, India. Mineralogy and Petrology, 60(1-2), 99-119.

10. Holler, W., Touret, J. L. R., \& Stumpfl, E. F. (1996). Retrograde fluid evolution at the Rampura Agucha Pb-Zn-(Ag) deposit, Rajasthan, India. Mineralium Deposita, 31(3), 163.

11. Staff, H. Z. L. (1992). Rampura-Agucha mine. Min Mag, 167, 372-375.

12. Mishra, B., \& Bernhardt, H. J. (2009) Metamorphism, graphite crystallinity, and sulfide anatexis of the Rampura-Agucha massive sulfide deposit, northwestern India. Mineralium Deposita, 44(2), 183.

13. Naha, K., \& Halyburton, R. V. (1974) Early Precambrian stratigraphy of central and southern Rajasthan, India. Precambrian Research, 1(1), 55-73.

14. Naha, K., \& Halyburton, R. V. (1977) Structural pattern and strain history of a superposed fold system in the Precambrian of Central Rajasthan, India. II. Strain history. Precambrian Research, 4(1), 85-111.

15. Naha, K., \& Roy, A. B. (1983) The problem of the Precambrian basement in Rajasthan, western India. Precambrian Research, 19(3), 217-223.

16. Raja Rao, C. S. (1976) Precambrian sequences of Rajasthan. Misc. Publ. Geol. Surv. India, 23, 497-516.

17. Ranawat, P. S., Bhatnagar, S. N., \& Sharma, N. K. (1988) Metamorphic character of Rampura-Agucha lead-zinc deposit, Rajasthan. Mem Geol. Soc. India, 7, 397-410.

18. Ranawat, P. S., \& Sharma, N. K. (1990) Petrology and geochemistry of the Precambrian $\mathrm{Pb}-\mathrm{Zn}$ deposit Rampura-Agucha, India. Regional Metamorphism of Ore Deposits, Verlag, 197-227.

19. Ray, J.N. (1982) An evaluation of the tectonic framework of the Rampura-Agucha zinc-lead deposit, Bhilwara District, Rajasthan. Indian Minerals, 34, 19-22.

20. Roy, A. B., Somani, M. K., \& Sharma, N. K. (1981) Aravalli-pre-Aravalli relationship: a study from the Bhindar region, southern Rajasthan. Indian Journal of Earth Sciences, 8, 119-30.

21. Roy, A. B. (2000) Structural investigation of the Rampura-Agucha Mine and Neighbourhood. Hindustan Zinc Ltd. Project Report, 30.

22. Sharma, D. K., \& Singh, T. N. (1990) Some petrographic and genetic aspects of Rampura Agucha Zinc-Lead deposit, District Bhilwara, Rajasthan, India. In proc. Pacific Rim Congress, 90, 515-520.

23. Sinha-Roy, S. (1989) Strike-slip fault and pull apart basins in Proterozoic fold belt development in Rajasthan. Indian Minerals, 43, 226-240 